\title{
SITUATING ONESELF WITHIN THE ESTONIAN LANGUAGE AND WORLD LITERATURE: IVAR IVASK'S RELATIONAL WAYS OF SELF-UNDERSTANDING
}

\author{
Aija Sakova \\ Senior Research Fellow \\ Estonian Cultural History Archives \\ Estonian Literary Museum, Estonia \\ aija.sakova@kirmus.ee \\ Marin Laak \\ Senior Research Fellow \\ Estonian Cultural History Archives \\ Estonian Literary Museum, Estonia \\ marin.laak@kirmus.ee
}

\begin{abstract}
The paper explores the relational ways in how the identity of a creative person is constructed in exile, in dialogue with the relational environments and proximate others. The case study for the article is the writer and literary scholar of Estonian and Latvian heritage, Ivar Ivask (1927-1992), who fled Latvia during World War II, spent some years in displaced persons' camps in Germany, later on studied German literature and art history in Marburg (Germany), and starting from 1950 lived and worked in the United States. Ivask's journey suggests that at points in his life he could have been a Latvian, an Estonian, a Baltic-German or even an English-speaking American.

The paper attempts to demonstrate the reasons why Ivask became, despite everything, an Estonian writer and how this had a great deal to do with the relational understanding of himself: his sensorial childhood experiences in southern Estonia and his mentors and other writers he admired (e.g. Bernard Kangro), who played a crucial role in his choosing Estonian to be the language of his poetry as well as his diaries. We further contend that by engaging himself with different literatures and authors from around the world in different languages, Ivask was constantly looking for new poetic and literary discoveries and perhaps therefore insights into himself. Reading other authors' work and relating himself to their writings meant he was therefore also engaging with his own identity. In this light, we contend that Ivask's literary criticism of other authors' work as well as his literary correspondences with them provides a model of how the social and
\end{abstract}


literary self can be constructed in exile, in dialogue with the relational environments and influences of proximate others, including respected authors, some of whom served as role models and mentors.

Keywords: autobiography, Estonian literature, identity, Ivar Ivask, life writing, multilingualism, relational self

\section{INTRODUCTION}

This article explores the relational ways in how the identity of a creative personality can be constructed in exile. The case study that is used for this paper is that of the writer and literary scholar of Estonian and Latvian heritage, Ivar Ivask (1927-1992), who fled Riga (Latvia) during World War II in 1944. He spent the years 1945-1946 in displaced persons' camps in Wetzlar and Wiesbaden in Germany (Ivask 2018: 129); in 1946-1950 he studied German, comparative literature, and art history in Marburg (Germany), and beginning in 1950 he lived and worked in the United States, mostly in Northfield, Oklahoma. The last year of his life (1992) Ivask spent in retirement in Ireland.

Ivar Ivask was born in Riga, to a Latvian mother Ilze Maria Gūters (18971937) and an Estonian father Friedrich Vidrik Ivask (1892-1975). German served as a common language at home (Laak 2018: 118). Winters were spent in the family's apartment situated in the same building that housed the Estonian Embassy in Riga, and summers at his father's birthplace and family farmhouse in Rõngu, southern Estonia (Rummo 1990: 6) Since the first shared language at home was German, Ivask's first poems at the age of 16 were also written in this language (Talvet 2003: 523; Tarvas 2006: 12). Later on Ivask admitted to have been inspired to write poetry by discovering R.M. Rilke's poetry books in his father's library. Ivask had self-published his early poetry in German under the name of Ivar Ivarsen in 1945, while being in a displaced persons' camp, but regretted it later and destroyed all the remaining copies of the book (Tarvas 2006: 12). Thus his publicly accessible German poetry book titled Gespiegelte Erde: Gedichte 1953-1963 (1967) was published in New York several years later than his first Estonian-language poetry book titled Tähtede tähendus: Esimene kogu luuletusi. 1958-1963 (The meaning of stars ${ }^{1}$ : The first collection of poems. 1958-1963 (1964)). Altogether, Ivask published eight poetry books in Estonian, and some of them were also illustrated by him; in fact, Ivask also considered himself to be an artist (Talvet 2010: 7; Rummo 1990: 6). His later poetry written in English was published under the heading Snow Lessons (1986). In the spring of 1986, as a reaction to the Chernobyl disaster, another series of poems in English, The Baltic Elegies, was written and published (Olesk 1987: 8). 
Ivask was not an active member of the Estonian or Latvian diaspora communities in the USA, and lived apart from them with his Latvian wife Astrid Ivask (1926-2015), whom he had met and married in Marburg in Germany in 1949. Professionally, Ivask was a German philologist by background and had specialized in Austrian literature. At the beginning of the 1960s, he had spent a year in Vienna and would later become a regular co-worker for the Austrian literary magazines Wort in der Zeit and Forum (Teder 1987: 1708). Later on he worked as a professor of German literature in Northfield, USA, and from 1967 was editor-in-chief of the literary magazine Books Abroad (from 1977 it has existed as World Literature Today). Thus his circle of friends and acquaintances covered the world. Working at the journal, Ivask's everyday activities also included finding literary talents and introducing them to the world. In 1969, he helped to establish the Neustadt International Prize for Literature at Books Abroad with the help of private financing (Tarvas 2006: 34). Amongst others, this prize was awarded to Gabriel García Márquez, Czesław Miłosz, and Octavio $\mathrm{Paz}$, all of whom would later receive the Nobel Prize for literature. Some other authors who would later be recipients of the same Nobel Prize had earlier been amongst the judges for the Neustadt Prize - Heinrich Böll, Odysseas Elytis, Joseph Brodsky, Derek Walcott, and Elie Wiesel (Tarvas 2006: 35).

A colleague of Ivar Ivask from World Literature Today has stated that Ivask spoke at least ten different languages (R[iggan] 1992: 791). He was also one of the few people in the Baltic countries who could read and speak all the three Baltic (Estonian, Latvian, Lithuanian) languages (Taagepera 1992: 2400). Having had several opportunities to use different languages as his main language of writing, Ivask makes some really interesting and remarkable choices. In 1958, he switches from writing his poetry in German to Estonian (Ivask 1986: 134). From 1959 onwards, despite not living continuously in an Estonian-language home, he surprisingly also chooses the Estonian language to be the language of his diaries.

Ivask's decisions to switch languages in his writing were by no means selfevident. He had been struggling with identifying himself as an Estonian and his lack of self-confidence in expressing himself in the Estonian language through his encounters with literature were especially acute at the beginning of the 1950s (Tarvas 2006: 18). He had even regarded Estonian literature not only as provincial but also unable to overcome its provinciality (Taagepera 1992: 2399).

The scale of the collection of Ivar Ivask's diaries and notes from his personal archive, preserved at the Estonian Cultural History Archives at the Estonian Literary Museum in Tartu reveals the immensity and prestigiousness of his literary networks: there are manuscript correspondences in several languages 
(English, German, Estonian, Spanish, Finnish, French, Latvian, and Lithuanian) with 523 people from all over the world. Some correspondences lasted for decades and some only for a few years. His archive also gives us a fascinating insight into the ways he understood himself, as it contains 57 volumes of his personal diaries written in manuscript form in Estonian. ${ }^{2}$

This article attempts to explore Ivask's multi-layered (Tarvas 2006: 18) and multilingual (Eisenreich 1967: 5; Jürma 1967: 4) identity. It also asks what made him situate himself within the Estonian language in terms of the writing of his diaries and poetry and at the same time not lose his multicultural perspective in order to become a world citizen in the truest sense. The article thus explores how Ivask understands himself within his diaries (and poetry), and who were his role models and reference points. Ivask's choices are analysed in this paper through the lens of him consciously building and reflecting, i.e. making peace with or combining the different parts of his identity.

\section{(AUTO)BIOGRAPHICAL NOTES FROM AND ABOUT IVAR IVASK}

In an interview in 1987, Ivask looks back at his life and tries to make sense of his multilingual identity:

I was born into a home where four languages were spoken. This alone made things complicated. My father was Estonian, my mother Latvian. Their mutual language was German. At school we had English, later on French, Spanish, and other languages. Somehow I never knew how to deal with only one language. For me it is hard to imagine somebody who thinks only in one language. (Olesk 1987: 8)

Ivask explains his interest in comparative literary studies through his multilingual home and through the different perspectives that languages have provided him with. He described himself metaphorically through an image of a tree that is rooted in one specific place but has grown quite big and has far-reaching branches. But he has also admitted that the merging or peaceful co-existence with the variety of languages and different national identities within him was not necessarily an easy task:

One of my earliest motivations was the endeavour to overcome or integrate the national, linguistic, and cultural differences of my home environment. Before I knew how to write, I tried to achieve it through drawing. (Ivask 1986: 132) 
Looking for parallels for his experience of a multicultural and multilingual Baltic home environment, Ivask finds a comparable melting pot of different cultural influences in Austria, where he lived for a year between 1960 and 1961. Ivask believed that Austria and Ireland were the places most similar to the Baltic states in Europe, largely because of the intersections and crossings of different languages and cultures there:

I believe that the same richness that exists in Austria, exists also in the Baltic countries. To be a refugee does not mean to become poorer but richer. Because, if we not only maintain the Estonian identity but become not only Europeans (as Gustav Suits wanted), but also world citizens cosmopolites with roots. That is an ideal to be achieved. (Olesk 1987: 8)

Austria and Austrian literature become like a substitute 'home' for Ivask and not only because of the cultural similarity that he feels they have with the Baltic countries but also due to the authors whose work he admired and with many of whom he had made close friends. In the preface written to Ivask's Germanlanguage poetry book, Herbert Eisenreich (1967: 7) called him an Austrian by choice or intellectually Austrian. One of Ivask's close friends, role models and literary loves was the Austrian writer Heimito von Doderer (1896-1966), who inspired him to keep a diary with regularity and who, amongst many other things, gave him his first new blank diaries.

On 17 December 1957 Ivask begins his first regular diary notes:

I was born at 9:15. today 33 years ago, in Riga, the capital of Latvia, and now I start my diary somewhere else - neither in the town of my birth nor in Estonia, nor in my current home, but in Austria. Am I old enough for keeping a proper diary? Let's hope so, because until now I have succeeded in it only temporarily, and I have been postponing keeping a diary regularly until I have gathered and sorted my previous autobiographical notes and written them anew... Since I haven't been able to do it so far, why not start with a completely new volume? I have just decided to do that. (Ivask 2018: 136)

Ivask (2018: 136) admitted that he had started to understand himself better because of his acquaintance with Doderer. He was introduced to the novelist, initially through his writings. He was impressed by the novel Die Dämonen. ${ }^{3}$ This was followed by direct correspondence with the author and a personal meeting in Munich in August 1957, as Ivask and his wife Astrid used to travel to Europe from their home in America every year. 
Ivask admits that he was influenced by Doderer's central belief "Die Erinnerung als Grundlage der Person" (memory forms the basis for the personality).

Here my growing interest in my own past had a start. This is a sign for becoming a human in the first place, becoming a mature human being (as I see and understand with growing clarity). (Ivask 2018: 136)

In 2016, after the death of Astrid, Ivask's personal archive was handed over to the Estonian Cultural History Archives at the Estonian Literary Museum. The archive as it stands today has been systematically organised and information about it is searchable via an electronic database. ${ }^{4}$ Ivask's first volume of handwritten diaries is titled Tagebücher 1956-1963 (Diaries 1956-1963), and contains also 100 loose pages of notes from previous years when he had attempted to start gathering information for a possible future autobiography. The second volume is titled Must kaustik: Päevikud 1964-1966 (Black volume: Diaries 1964-1966), and the third one Hall kaustik: Päevikud 1967-1968 (Grey volume: Diaries 1967-1968). After these three tomes, each year is kept in a separate volume until his death in 1992.

In the first few years of keeping a diary (especially on the loose pages) Ivask writes in German as well as in Estonian. However, starting from 7 July 1959, he switches over, after the first sentence "Masings Gedichte sind erschienen" (Masing's poems have been published) to Estonian for good..$^{5}$ From that point onwards, his diary entries are entirely in Estonian (Laak 2018: 121).

Although Ivask never published an autobiography, there is strong evidence to contend that his desire to start keeping a diary as "memory support" (Ivask 2007: 48) was also connected with a wish to write one. His first few diary volumes contain notes that could be easily identified as a precursor to constructing an autobiography. For example, he begins a diary entry with the title "My life story (1927-1961). From Riga to Europe (From the Baltic Sea over the Atlantic to the Mediterranean Sea)"6 and enumerates periods in his life:

I. 1927-1937 Between Riga and Rõngu (The myth of a happy childhood);

II. 1937-1947 From Riga to Marburg (The time of my "second reality"!);

III. 1947-1957 From Marburg to Northfield (Transition time, maturing);

IV. 1957-1961 From Northfield to Europe (Second independency, "Vtoroe rozhdenie"7 (Second Birth), the freedom of clarity). (F. 409, m 27: 1-21)

Ivask's primary intention of keeping diaries was for personal recollection. "The role of the diary is to be cathartic. Definitely for the diary keeper. The publishing of diaries in order that others have part of it is a lot more problematic." 
(Ivask 2007: 48) Despite the fact or exactly because a diary is an intimate space, the possibility to work with them later can lead scholars "to the most profound insights" (Arthur \& Kurvet-Käosaar 2019: 1). Under the cover of the mundane, shifts in the individual's views or changes in the external world can be knowingly or unknowingly recorded (Ben-Amos \& Ben-Amos 2020: 1).

Although the fact that Ivask kept diaries over a period of 35 years proves his private nature, he was also a very active social figure (Talvet 2003: 531) and liked making connections with the authors he admired largely through correspondence (Sakova 2018: 154). For example, he tried to introduce Heimito von Doderer to the Russian poet Boris Pasternak, with whom he was also corresponding (Sakova forthcoming), and he succeeded in initiating a correspondence between Doderer's secretary Wolfgang Fleisher and Estonian poet and translator Ain Kaalep (Tarvas 2006: 28).

Thus Ivask's diaries not only record his intimate thoughts but they also come across as recordings of his intellectual thoughts and deeds. They are beautifully written, often including drawings and doodles. The loose pages contain lists for each year (between 1957 and 1961) of the people he met, travels undertaken, reviews published, accounts of correspondences, etc. This shows not only how systematic Ivask was, but also that he valued contacts with people and how he saw himself in relation to others.

\section{THE MULTILINGUAL AND RELATIONAL SELF}

Although Ivask was a refugee, it is hard to consider his choice of the Estonian language as one of his main poetic languages and the language of his diaries as a longing for a lost home. His identity was hybrid and multilingual from the start, and tends not to fit into the frameworks of understanding Estonian 'old-diaspora' communities where 'Estonianness' was understood as communal rather than individual (Ojamaa \& Karu-Kletter 2014: 193). In overviews of Estonian exile literature Ivask is considered to be an exceptional figure, a cosmopolite and sovereign entity (Kepp 2008: 493).

Current research on individuals with diasporic and multicultural backgrounds has started to shift the emphasis from cultural and territorial aspects of belonging to the "individuals as independent actors" and their individual capacities (Janassary 2015: 155). Research on Estonian diaspora communities also shows a shift towards open identities, i.e. hybrid identities (Valk \& KaruKletter \& Drozdova 2011). In relation to Homi Bhabha (1994: 53) hybrid identity is often understood as a "third space", a space in between, where cultural 
differences and the ambiguities of a self are manifested and played out (Hein 2006: 41), but also a space where the peace-making capacity of an individual can evolve (Janassary 2015: 160).

Elina Mikkilä (2020) has convincingly investigated today's writers who are without one fixed homeland and native language, and she suggests in her article "Literary Biographies Without Fixed Linguistic Abode" a typology to describe authors with multilingual backgrounds. Thus language and poetry, or the exile itself, can become one's home (Saresma 2019: 203).

Similarly to Homi Bhabha (1994: 63), to whom existence means "to be called into being in relation to an otherness", Paul John Eakin (1999: 43) has shown that "all identity is relational". Anne Rüggemeier (2014), who has adopted Eakins concept, analyses migrant (life) stories in English-language literature as relational autobiographies. Since we are interested in the ways that Ivask related himself to the physical and mental environments around him and to authors whose work he admired, we will take a closer look into Rüggemeier's and Eakin's relationality concepts.

Rüggemeier speaks of relational autobiographies that are always a "staging of dialogues" (Rüggemeier 2014: 63). Partly relying on Eakin's views and theories, she proposes five different ways of how rationality is and how it can be staged within writing in order to understand the self:

1) Staging a dialogue between 'I' and the relational other;

2) Staging a dialogue between 'I' and a collective relational context;

3) Staging a dialogue between 'I' and the-self-as-the-other;

4) Staging a dialogue between the reader and the text;

5) The relational autobiography as a dialogue with the conventional autobiography and its cultural codes. (Rüggemeier 2014: 64-69)

In Eakin's work we find four categories of a relational self:

1) From 'I' to 'you': modelling the social self;

2) From 'you' to 'I': relational environments;

3) Dealing with the proximate other;

4) The self as other. (Eakin 1999: 61-98)

We can see that some of the categories of the relational self that Eakin and Rüggemeier describe are overlapping: both speak of a dialogue between the 'I' and the 'self as the other', meaning that autobiography offers a possibility to explore the self in the past as another person; both also have a category 
that stresses the importance of the 'proximate other' or 'relational other' for understanding and writing about the self. Rüggemeier underlines also the importance of the dialogues between the reader and the text and between the text, the autobiography, and cultural and conventional codes.

Concentrating on staging the dialogue between the ' $\mathrm{I}$ ' and the other(s) as well as between 'I' and the collective contexts and relational environments, we see that Rüggemeier puts more emphasis on the cultural collective environment, whereas Eakin understands environment more literally. His example of Leslie Marmon Silko's Storyteller tells a story of a person conveyed through pictures and landscapes (Eakin 1999: 69). Photographs of the Laguna Pueblo reservation in New Mexico, where the author grew up, as well as pictures of her family members, are put next to short stories and thus reflect and convey the culture of oral story-telling where the author comes from. Thus Eakin suggests that through the telling of the story of her heritage community, Silko also tells a story of herself, because she cannot imagine herself as distinct from those landscapes and of the oral story-telling tradition.

Leena Kurvet-Käosaar (2019: 161) has drawn attention to the interrelations of space and subjectivity in life-writing studies, and has convincingly shown to us how real experienced landscapes play a crucial role in self-understanding in exile. Through the example of Estonian-Swedish writer Käbi Laretei, she has shown how "it is through landscapes that different sides of intimate relationships in her life are often tackled" (Kurvet-Käosaar 2019: 168).

Returning now to the interrelations between the 'I' and the other(s), it is relevant to note that what Rüggemeier understands as staging a dialogue between 'I' and the 'relational other' is for Eakin about dealing with the 'proximate other'. Usually, the relational or proximate other is seen as a close family member, often a parent or other close relative. It is interesting that Eakin devotes a whole subchapter to the modelling of the social self, where he further elaborates the misconceptions of understanding the self as an autonomous being. Engaging with the psychologist John Shotter, Eakin explains that the understanding of the 'I' as an isolated individual that already contains everything (i.e. mind and mentalities) has to do with the fact that we are disciplined to talk and understand ourselves in this way because of social accountability (Eakin 1999: 62). Together with Shotter, Eakin proposes that we should not take the inner subjectivity of the individual as the basic but rather "the practical social processes going on 'between' people" (Shotter as cited in Eakin 1999: 62).

In the following section we will take a closer look into how Ivask related himself to his childhood landscapes and how they became relevant in his shift to Estonian as his poetic language and of his later self-understanding. We will 
also explore who are the relational or proximate others for Ivask and whether his network of writers whom he admired can be understood as an explanation for his way of building his identity.

\section{ESTONIAN BECOMES THE LANGUAGE OF IVASK'S POETRY AND DIARIES}

When Ivask looks back at the beginnings of his writing and describes how he wrote his first poem "Hände" ("Hands") in German at the age of 16, under the influence of Austrian poet Rainer Maria Rilke (1875-1926) in 1943, he asks himself retrospectively: "Why in German?"

Mother died of cancer in January 1937 when I was nine. Despite that German still felt a language that connected them both. And wasn't Rilke form the provincial Prague, denying his 'Germanness' as an Austrian, using German only as a means for his European literature? Wasn't it possible for a young Baltic man not to be accused of his 'Germanness' or of denying his own nation? (Ivask 1986: 133)

Considering that his home language was to a great extent German and his student years and the years of his youth were spent in Germany, it would be rational to assume that Ivask could have become a German-language poet; yet, it did not happen. Ivask's interest in Estonian literature arises shortly after or parallel to his studies of German literature in Marburg (Sakova: 2018). In 1951, Ivask established contact with the Estonian exiled writer Bernard Kangro (1910-1994), who lived in Sweden and had become editor-in-chief of the Estonian diaspora's literary journal Tulimuld (Fire-Earth).

It was solely due to Bernard Kangro's poetic influence and admiration for his poetry that Ivask turned to Estonian literature (Sakova 2018: 152). It has also been claimed that Kangro had rescued Ivask from not being lost to Estonian literature (Taagepera 1992: 2399). In 1951, Ivask had asked Kangro whether he could help him acquire some Estonian books (F. 309, m 61: 1). Ivask had also critiqued Estonian literature and Estonian literary criticism in general and thus Kangro urged him to write about the situation of contemporary Estonian poetry, its translations and status within the larger European context (Hollo forthcoming). Ivask (1951) took up Kangro's challenge and published his first article in Estonian. 
This was soon followed by several other articles written in Estonian on Estonian, Spanish, and German literatures. His first book reviews in English were published in 1956, in the quarterly literary magazine Books Abroad, the magazine of which he would become the editor-in-chief twelve years later. In Books Abroad, Ivask published a review of Bernard Kangro's novel Peipsi (Peipus) (2/1956) and a review of Osip Mandelshtam's collection Sobranie sochinenii (Collected works) (3/1956).

Ivask's shift to the use of Estonian in his diaries was related to his growing need to express his thoughts and critical elaboration on Estonian literature and literary criticism (Laak 2018: 121). Next to writing about Estonian, German, Austrian, English, Spanish, and Russian literatures, he also engaged in correspondence with several Estonian diaspora authors - Marie Under, Bernard Kangro, Ants Oras - all starting in the 1950s. For Ivask the correspondence with Ants Oras (1900-1982), a professor of literature, became a sort of substitute for his master's studies in Estonian literature.

The most significant contributing factor for Ivask to start writing, besides criticism, also poetry and diaries in Estonian, was the 14 summers that he and Astrid spent in Finland between 1958 and 1985 (Ivask 1986: 134). There, in the middle of eastern Finland's lake landscape, on Vaahersalo Island, "watching the falling stars and fish jumping out of the water", he tried to put his experiences into words in German but failed after the first stanza:

The noble language of Rilke and Goethe seemed suddenly unsuitable for this primal Finno-Ugric vision, which corresponded very well with another language, my father's language, which I had been using so far only to write criticism. (Ivask 1986: 134)

Suddenly, being in Finland - physically the closest place to the landscapes that he knew from his childhood - Ivask reconnects to its sensorial memories and feels the language that he has not been using for poetry so far is now appropriate for expressing his experiences and feelings. Thus Ivask's first poems in Estonian begin to emerge in Finland in August 1958, at the age of 30; in his diary excerpts from that year, he notes that "Ö̈̈" (The night), "Soomes" (In Finland), and "Muutus" (Change) have been born (F. 409, m 27: 1). In a letter to Bernard Kangro in November 1958 he admits that the summer has been the richest experience since the ones he has had in Rõngu. "Also, Astrid was so inspired by the Finno-Ugric atmosphere that she learned the Estonian language on the spot." (F. 310, m 61: 1) 
When we examine Ivask's notes in "My life story (1927-1961)" more closely, we discover that a great deal of his childhood memories are connected with the summers (from May to September) spent in Rõngu, southern Estonia. One can see how vividly he describes the smells, visual images and sounds of the time spent there:

Arriving in southern-Estonian nature in early summer: the blueness of the air, the freshness, the singing of skylarks, the smell of fresh earth! Long summer nights, fresh cow milk or sour milk with kama, crispy-soft rye bread (before that, the taste of cabbage leaves), raspberries as dwarf hats, currants with sugar before going to sleep. (Ivask 2018: 127)

And Ivask goes on, remembering the smell of trees and lilac bushes, the colour of coloured pieces of glass, the sound of the grandfather clock, etc. After mentioning a number of things and people relevant to him from his childhood, he also enumerates the Estonian language and the Tartu dialects around him. The sound of the Estonian language thus becomes part of his sensorial childhood experiences.

Looking into Ivask's language of poetry that Paul Eerik Rummo (1990: 7) has described as very personal and almost diary-like, one discovers the image of a veranda that becomes like "a cathedral, massive and strong, but remains at the same time light and leading the way" (Uibopuu 1982: 108). The physical veranda of his 80-page-long "Veranda" poem (Ivask 1990) is located in his childhood memories in Rõngu, but it grows into being something much bigger, and in the poem "Veranda" it is described as a roadmap (1990: 30), a secret lantern (ibid.: 33), a light house (ibid.: 39), a protective eggshell (ibid.: 45), and a key (ibid.: 48) respectively. Thus the veranda might be the key to the poetics, ethics as well as aesthetics of the poet as the lyrical 'I' suggests (Ivask 1990: 49). Veranda as part of Ivask's sensorial childhood recollections becomes a metaphor for Ivask's values and beliefs and it also incorporates a poetic home, a reference point. The southern-Estonian landscapes become a cornerstone of his identity and help build - through the Finnish landscape - an intimate relationship with the Estonian language.

\section{UNDERSTANDING ONESELF VIA OTHERS}

Next to Ivask's "My life story (1927-1961)", which is part of the first volume of his diary, Tagebücher 1956-1963, he also compiled other lists of important phases of his life that may serve as a possible "table of contents" for his future 
autobiography. We can estimate that it was probably around the beginning of 1960 that Ivask must have compiled the list "Potential autobiography" (F. 409, $\mathrm{m}$ 27: 94). This list is interesting and relevant because it gives us an insight into how Ivask thought of himself and how he related himself to other authors.

He began the list with his family tree, and then enumerated the places where he had lived and which were connected with important periods in his life. After that he switched to compiling lists of composers and writers who had had a great influence on him:

1. The Ivasks (1700-1860);

2. Riga - Rõngu (1927-1937, 1937-1944);

3. [Rainer Maria] Rilke and Austrian literature;

4. Marburg: Astrid, [Ernst] Kelle;

5. Minneapolis - Bonn, [Hugo von] Hofmannsthal;

6. Northfield - cats, lecture on novels;

7. [Jean] Sibelius and Finland;

8. [Werner] Milch and German literature;

9. [Marie] Under and Estonian literature;

10. [Jorge] Guillén and Spanish literature;

11. [F.R.?] Leavis and English literature;

12. [Paul] Valéry and French literature;

13. [Bernard] Kangro and my Estonian interests;

14. [Ivar] Grünthal and "Mana";

15. [Wolfgang Amadeus] Mozart, [Béla] Bartók and music;

16. [Boris] Pasternak and Russian literature. (F. 409, m 27: 94)

Ivask includes in this list some of his lecturers on art history (Kelle) and German literature (Milch) from his Marburg university period, ${ }^{8}$ some authors from Austrian literature (Hofmannsthal and Rilke), and poets whom he admired (Guillén, Valéry, Under, and Kangro).

What seems particularly striking is the fact that this list, on a rather small piece of paper, written on both sides, is put down under the heading "Potential autobiography" and not, for instance, "My influencers" or "My role models", and that it also contains important biographical life 'stations' (places) and persons 
(like his wife Astrid) as well as authors whom Ivask had never met and personally known. One might need to add that some of the authors enumerated eventually became his friends through correspondence.

It is remarkable that the proximate others for Ivask are not only family members (Ivask's ancestors and his wife Astrid are mentioned) but also the foremost authors whose work he admires. Thus one can argue that Ivask consciously creates his own proximate or relational others. He establishes and maintains contact with the authors whose work he has admired to varying degrees throughout his life (Sakova 2018: 154).

In 1952 Ivask made contact with Spanish writer Jorge Guillen after he had published an article on Spanish poetry in Tulimuld (Ivask 1952). In 1957, he contacted and met Austrian writer Heimito von Doderer, and in 1959 he wrote to Russian author Boris Pasternak after having reviewed his novel Doctor Zhivago in the magazine Books Abroad (Ivask 1959).

Interestingly enough, Heimito von Doderer is not mentioned in this list as an author for his potential autobiography although we know that in 1960-1961, when Ivask spent a whole year in Vienna with the intention of writing a monograph on the Austrian novel, Doderer had become his trustee and close friend (Undusk 2016; Tarvas 1997a, 1997b). Thus it is likely that Ivask just forgot to make a note about Doderer and/or perhaps thought of it in a similar vein to another significant influence in his life, Rainer Maria Rilke.

For Ivask, the discovery of Rilke's poetry had been a significant moment of enlightenment or epiphany, which he came back to regularly, and he referred to him not only in his diaries (Ivask 2007: 31) but also in letters and essays. In a similar vein, he tried to situate the discovery of Pasternak's poetry for himself in time and space. In an essay about Pasternak, Ivask wrote:

It was as a student at the University of Marburg in 1947 that I discovered the strongly pulsating, cosmically encompassing poetry, and also that he, too, had been a student at Marburg back in 1912. (Ivask 1970: 195)

Ivask considered himself primarily as a poet and only after that as a scholar and critic (Sakova 2018: 153). Also it should be reminded that the network of people and authors whom Ivask admired and with whom he felt a connection, a relatedness, existed prior to when he had become the editor-in-chief of the world literature magazine. For Ivask, it was only natural to make contact with his fellow poets - often a great deal more experienced and known than himself - especially those whose work he admired.

Ivask hardly ever wanted to speak about his views on writing and poetry directly; instead he preferred to do it through the views of other authors (Veldi 
1995: 900). He was particularly interested in the ones whom he considered to be "world authors" or the ones belonging to world literature: the authors "whose heritage neither narrows nor dictates their being or creativity" (Veldi 1994: 923). The examples of Ivask's autobiographical notes and his correspondences with other authors illuminate and illustrate how intertwined his self-understanding was with his comprehension of the work of other authors he genuinely admired.

Not only did Ivask feel the need to relate himself to his childhood environments and some of his close family members - especially his wife Astrid - but he also felt a need to continuously relate himself to his fellow writers, to make connections and build relationships. The works of these writers, their views on poetics and aesthetics, became part of his own identity.

\section{CONCLUSION}

The aim of the paper was to look at the relational ways of how the identity of a creative person can be constructed in exile. Ivar Ivask was a man from a multilingual family, who could have chosen to be a Latvian, an Estonian, a German or to become an English-speaking American. We have attempted to show that the reasons for him to choose Estonian as the language of his poetry and diaries has plenty to do with his relational understanding of himself. His sensorial childhood experiences and the reconnection with them in Finland appear to have played a great role in his turning back to the language that was part of his childhood summers. Also, we suggest that becoming fond of some Estonian authors and being encouraged by the exiled Estonian poet Bernard Kangro to engage with more Estonian literature would have played a great role in his choosing to express himself increasingly and frequently in Estonian (along with German and English).

A close reading of Ivask's diaries and autobiographical notes has also revealed who else could have been his relevant literary discoveries and influences. We suggest that, because he perceived himself primarily as a poet, he also needed to discover himself in the poetry of other authors. In trying to sketch a potential autobiography, Ivask did not only refer to his childhood and family members but also to all the other authors (writers as well as composers) who had been a discovery and of significant value to him, in whose works he had detected something relevant and insightful about himself.

Understanding himself through others and in a constant relationship to other authors (through book reviews as well as direct correspondences with them), Ivask was not only engaging with literature and the authors he admired 
but at the same time also with himself, his identity, and with who he was. He was in search for his values. Thus his literary criticism as well as his literary correspondences could be viewed as the modelling of his social and literary self and could perhaps serve to understand other writers with similar backgrounds, of whom there are admittedly very few.

\section{ACKNOWLEDGEMENTS}

The article was supported by the research grant of the Estonian Literary Museum, EKM 8-2/20/1, the research grant of the Estonian Ministry of Education and Research "Source Documents in the Cultural Process: Estonian Materials in the Collections and Databases of the Estonian Literary Museum" (EKKD65), and by the Centre of Excellence in Estonian Studies (TK 145) through the European Regional Development Fund.

\section{NOTES}

1 The Estonian word 'täht' also means 'letter', so the heading could also be translated as 'The meaning of letters'.

2 Ivar Ivask's archive at the Estonian Cultural History Archives is EKM EKLA, F. 409.

${ }^{3}$ Ivask wrote several reviews of Heimito von Doderer's novel in English and Estonian. The English review was published in Books Abroad, 4/1956 (Sakova 2018: 155).

4 The electronic database Ellen of the Estonian Cultural History Archives can be found at http://galerii.kirmus.ee:8888/ellen.

5 This is also proved by the fact that the first volume is in German and the following ones in Estonian.

6 Originally in Estonian, as well as the following subtitles.

7 In Russian in the original.

8 More about the influence of Werner Milch see in Aija Sakova's article (2018). 


\section{ARCHIVAL SOURCES}

Estonian Cultural History Archives at the Estonian Literary Museum (EKM EKLA):

F. 409 - Ivar Ivask's manuscript collection

F. 310 - Bernard Kangro's manuscript collection

\section{REFERENCES}

Arthur, Paul Longley \& Kurvet-Käosaar, Leena 2019. Introduction: Thresholds and Boundaries. In: Paul Longley Arthur \& Leena Kurvet-Käosaar (eds.) Border Crossings: Essays in Identity and Belonging. New York and London: Routledge, pp. 1-6.

Ben-Amos, Batsheva \& Ben-Amos, Dan 2020. Introduction. In: Batsheva Ben-Amos \& Dan Ben-Amos (eds.) The Diary: The Epic of Everyday Life. Bloomington: Indiana University Press, pp. 1-22.

Bhabha, Homi K. 1994. The Location of Culture. London \& New York: Routledge.

Eakin, Paul John 1999. How Our Lives Become Stories: Making Selves. Ithaca \& London: Cornell University Press.

Eisenreich, Herbert 1967. Vorwort. [Preface.] In: Ivar Ivask. Gespiegelte Erde: Gedichte 1953-1963. [Reflected Earth: Poems 1953-1963.] New York: Frederick Ungar Publishing, pp. 5-7.

Hein, Kerstin 2006. Hybride Identitäten: Bastelbiografien im Spannungsverhältnis zwischen Lateinamerika und Europa. [Hybrid Identities: Crafted Biographies in a Tension between Latin America and Europe.] Bielefeld: transcript Verlag.

Hollo, Maarja forthcoming. Valgete ööde peegeldus: Ivar Ivaski ja Bernard Kangro dialoog kirjades. [The Reflection of White Nights: Ivar Ivask's and Bernard Kangro's Dialogue in Letters.] Tuna, No. 3.

Ivask, Ivar 1951. Mõtteid eesti kirjanduskriitika ülesannetest. [Thoughts on the Tasks of Estonian Literary Criticism.] Tulimuld, No. 4, pp. 255-260. Available at https://www.digar.ee/viewer/et/nlib-digar:348476/304278/page/17, last accessed on 1 June 2020.

Ivask, Ivar 1952. Hispaania luulest ja J. Guillén'ist. [On Spanish Poetry and J. Guillén.] Tulimuld, No. 2, pp. 93-98. Available at https://www.digar.ee/viewer/et/nlibdigar:348482/304273/page/33, last accessed on 1 June 2020.

Ivask, Ivar 1959. Doctor Zhivago by Boris Pasternak. Books Abroad, Vol. 33, No. 1, pp. 33-34. DOI: 10.2307/40097669.

Ivask, Ivar 1964. Tähtede tähendus: Esimene kogu luuletusi (1958-1963). [The Meaning of Stars: First Collection of Poems 1958-1963.] Lund: Eesti Kirjanike Kooperatiiv.

Ivask, Ivar 1967. Gespiegelte Erde: Gedichte 1953-1963. [Reflected Earth: Poems 19531963.] New York: Frederick Ungar Publishing. 
Ivask, Ivar 1970. Introduction: The Poplar Is King. Books Abroad, Vol. 44, No. 2, pp. 195196. Available at https://www.jstor.org/stable/40124304, last accessed on 4 June 2020.

Ivask, Ivar 1986. Mõtteid oma loomingust. [Thoughts about My Writing.] Tulimuld, No. 3, pp. 132-135. Available at https://www.digar.ee/viewer/et/nlibdigar:353047/307057/page/21, last accessed on 1 June 2020.

Ivask, Ivar 1990. Verandaraamat ja teisi luuletusi. [Veranda Book and Other Poems.] Tallinn: Eesti Raamat.

Ivask, Ivar 2007. Olla need, kes me oleme. [To Be Who We Are.] Tartu: EKM Teaduskirjastus.

Ivask, Ivar 2018. Tagebücher 1957-1963. [Diaries 1957-1963.] Tuna, No. 4, pp. 126-136.

Janassary, Anita 2015. Diasporic Individuals - A Hidden Peace Building Capacity? In: Florian Kläger \& Klaus Stierstorfer (eds.) Diasporic Constructions of Home and Belonging. Berlin \& Boston: De Gruyter, pp. 147-162.

Jürma, Mall 1967. Paljukeelne Ivask. [Multilingual Ivask.] Vaba Eesti Sõna, 24 August, pp. 4-5.

Kepp, Õnne 2008. Ivar Ivask. In: Piret Kruuspere (ed.) Eesti kirjandus paguluses XX sajandil. [Estonian Literature in Exile in the 20th Century.] Tallinn: Underi ja Tuglase Kirjanduskeskus, pp. 491-494.

Kurvet-Käosaar, Leena 2019. 'A Spatially Scattered Being': Imagining Space in Baltic Exile Life Writing. Trames: A Journal of the Humanities and Social Sciences, Vol. 23, No. 2, pp. 159-172. https://doi.org/10.3176/tr.2019.2.03.

Laak, Marin 2018. Globaalne Ivar Ivask ja Eesti. [Global Ivar Ivask and Estonia.] Tuna, No. 4 , pp. $118-125$.

Mikkilä, Elina 2020. Literary Biographies without Fixed Linguistic Abode. Folklore: Electronic Journal of Folklore, Vol. 79, pp. .

Ojamaa, Triinu \& Karu-Kletter, Kristel 2014. Diasporaa-eestlaste enesekuvand muutuvas maailmas. [The Self-Image of Diaspora Estonians in the Changing World.] Methis: Studia humaniora Estonica, Vol. 10, No. 13, pp. 173-196. https:// doi.org/10.7592/methis.v10i13.1309.

Olesk, Ilmar 1987. Vestlus prof. I. Ivaskiga. [Interview with Prof. I. Ivask.] Teataja, No. 3, p. 8. Available at https://dea.digar.ee/page/teatajapoliit/1987/02/14/8, last accessed on 27 May 2020.

R[iggan], W[illiam] 1992. In Memoriam Ivar Ivask. World Literature Today, Vol. 66, No. 4, pp. 791-792.

Rüggemeier, Anne 2014. Die relationale Autobiographie: Ein Beitrag zur Theorie, Poetik und Gattungsgeschichte eines neuen Genres in der englischsprachigen Erzählliteratur. [Relational Autobiography: A Contribution to the Theory, Poetics and Genre History of a New Genre in English-Language Literature.] Trier: Wissenschaftlicher Verlag Trier.

Rummo, Paul-Eerik 1990. Saateks. [Preface.] In: Ivar Ivask. Verandaraamat ja teisi luuletusi. [Veranda Book and Other Poems.] Tallinn: Eesti Raamat, pp. 5-12. 
Sakova, Aija 2018. Reading Estonian Literature through a German Lens: How Ivar Ivask Became a World-Renowned Literary Scholar. Methis: Studia humaniora Estonica, Vol. 17, No. 21/22, pp. 150-162. https://doi.org/10.7592/methis.v17i21/22.14591.

Sakova, Aija forthcoming. Kuna elus ei ole juhuseid või ei ole ainult juhuseid... Ivar Ivaski kirjad Boris Pasternakile 1959. aasta sügistalvel. [Since There Are No Coincidences in Life or There Are Not Only Coincidences... Ivar Ivask's Letters to Boris Pasternak in the Autumn of 1959.] Slavica Revaliensa.

Saresma, Tuija 2019. Mohsen Emadi - A Poet of Exile. Trames: A Journal of the Humanities and Social Sciences, Vol. 23, No. 2, pp. 203-221. https://doi. org/10.3176/tr.2019.2.06.

Taagepera, Rein 1992. Ivar Ivask mõõdupuuna. [Ivar Ivask as a Yardstick.] Akadeemia, No. 11, pp. 2399-2401. Available at https://www.digar.ee/arhiiv/nlib-digar:101281, last accessed on 1 June 2020.

Talvet, Jüri 2003. Ivar Ivask kirjanduse tundjana. [Ivar Ivask as an Expert of Literature.] In: Ivar Ivask. Tähtede tähendust tunda. [To Know the Meaning of Letters.] Tartu: Ilmamaa, pp. 523-535.

Talvet, Jüri 2010. Ivar Ivask maailmakirjanduse sammast voolimas. [Ivar Ivask Chiselling the Column of World Literature.] In: Ivar Ivask. Hetked igavikust. [Moments from Eternity.] Tartu: Ilmamaa, pp. 7-13.

Tarvas, Mari 1997a. Ivar Ivask ja Heimito von Doderer. [Ivar Ivask and Heimito von Doderer.] Keel ja Kirjandus, No. 12, pp. 831-840. Available at https://www.digar. ee/arhiiv/et/perioodika/35033, last accessed on 1 June 2020.

Tarvas, Mari 1997b. Ivar Ivask als Vermittler zwischen den Kulturen: Am Beispiel seiner Auseinandersetzung mit der österreichischen Literatur. Diss. (PhD Thesis). University of Vienna.

Tarvas, Mari 2006. Ivar Ivaski tee Rõngust suurde maailma: kodu on keeles ja luules. [Ivar Ivask's Path from Rõngu to the World: Home within Language and Poetry.] In: Mari Tarvas. Ivar Ivaski personaalbibliograafia. [Ivar Ivask's Bibliography.] Tallinn: Keel ja Kirjandus, pp. 7-50.

Teder, Eerik 1987. Riia - Rõngu - Oklahoma: Pilguheit Ivar Ivaski elule ja loomungule. [Riga - Rõngu - Oklahoma: A Glance at Ivar Ivask's Life and Oeuvre.] Looming, No. 12, pp. 1707-1710. Available at https://www.digar.ee/arhiiv/et/perioodika/8686, last accessed on 1 June 2020.

Uibopuu, Valev 1982. Veranda võim. [The Power of the Verandah.] Tulimuld, No. 2, pp. 105-108. Available at https://www.digar.ee/arhiiv/et/perioodika/98658, last accessed on 1 June 2020.

Undusk, Jaan 2016. Ivask ja Doderer: Meeste sõprus. [Ivask and Doderer: The Friendship of Men.] In: Jaan Undusk. Eesti kirjanike ilmavaatest. [On World Views of Estonian Writers.] Tartu: Ilmamaa, pp. 544-558.

Veldi, Kerttu 1994. Odisseas Elitis ja Ivar Ivask: Kannatus ühise keele puudumise pärast. [Odysseas Elytis and Ivar Ivask: Suffering Because of the Lack of a Common Language.] Akadeemia, No. 5, pp. 921-926. Available at https://www.digar.ee/ arhiiv/et/perioodika/36861, last accessed on 1 June 2020. 
Veldi, Kerttu 1995. Teel harmoonia poole: Ivar Ivask ja Odisseas Elitis [On a Way Towards Harmony: Ivar Ivask and Odysseus Elytis.] Akadeemia, No. 5, pp. 899916. Available at https://www.digar.ee/arhiiv/nlib-digar:101561, last accessed on 1 June 2020.

Veldi, Kerttu 1996. On a Way Towards Harmony: Ivar Ivask and Odysseus Elytis. Interlitteraria, No. 1, pp. 145-161. Available at https://dspace.ut.ee/ handle/10062/54838, last accessed on 1 June 2020.

Valk, Aune \& Karu-Kletter, Kristel \& Drozdova, Marianna 2011. Estonian Open Identity: Reality and Ideals. Trames: A Journal of the Humanities and Social Sciences, Vol. 15, No. 1, pp. 33-59. https://doi.org/10.3176/tr.2011.1.02.

Aija Sakova is Senior Research Fellow (PhD) at the Estonian Cultural History Archives of the Estonian Literary Museum, Estonia. Her main research areas are memory studies, poetics of remembrance, multiculturalism, cultural transfer and cultural heritage.

aija.sakova@kirmus.ee

Marin Laak is Senior Research Fellow (PhD) at the Estonian Cultural History Archives of the Estonian Literary Museum, Estonia. Her main research areas are literary criticism, Estonian literary history, exile literature, digital humanities, literary networks, and cultural heritage.

marin.laak@kirmus.ee 